\title{
Pemodelan 3D Struktur Bawah Permukaan Gunung Anak Ranakah dan Sekitarnya Menggunakan Metode Gravitasi
}

\section{D Modelling of Subsurface Structures of Mount Anak Ranakah and Surrounding Using Gravity Method}

\author{
Desiderius Jarut $^{1}{ }^{*}$, I Ketut Sukarasa ${ }^{1}$, Ida Bagus Alit Paramarta ${ }^{1}$ \\ ${ }^{1}$ Program Studi Fisika, Fakultas Matematika dan Ilmu Pengetahuan Alam, Universitas Udayana, \\ Kampus Bukit Jimbaran, Badung, Bali, Indonesia 80361 \\ Email:*jarutdarius10@gmail.com, iketutsukarasa@unud.ac.id,paramarta@unud.ac.id
}

\begin{abstract}
Abstrak - Telah dilakukan penelitian pemodelan 3D struktur bawah permukaan Gunung Anak Ranakah dan sekitarnya. Penelitian ini bertujuan untuk membuat peta serta menentukan nilai anomali bouguer lengkap, anomali regional, anomali residual, nilai densitas bawah permukaan serta membuat model 3D struktur bawah permukaan. Data yang digunakan merupakan data sekunder yaitu data anomali gravitasi satelit yang diperoleh dari website Topex. Pengolahan data dalam penelitian ini menggunakan metode gravitasi. Pada metode ini akan dilakukan koreksi gravitasi, membuat peta anomali bouguer lengkap, melakukan analisis spektrum, melakukan pemisahan anomali regional dan residual menggunakan filter butterworth serta melakukan inverse modelling dengan menggunakan software ZondGM3D untuk membuat model 3D struktur bawah permukaan. Hasil peta anomali bouguer lengkap menunjukkan nilai anomali daerah penelitian antara 134,6-209,3 mGal, anomali regional 147,4-205,9 $m G a l$ dan anomali residual antara (-12,8)-11,0 mGal. Hasil inverse modelling menunjukkan bahwa struktur geologi bawah permukaan Gunung Anak Ranakah dan sekitarnya memiliki rentang densitas antara 1,2-3,0 g/ $\mathrm{cm}^{3}$, sehingga dari rentang nilai densitas batuan dapat diperkirakan struktur geologi bawah permukaan Anak Gunung Ranakah dan sekitarnya terdiri dari batuan soil $\left(1,2-2,3 \mathrm{~g} / \mathrm{cm}^{3}\right)$, andesit 2,40-2,80 $\left.\mathrm{g} / \mathrm{cm}^{3}\right)$ dan basalt $\left(2,70-3,0 \mathrm{~g} / \mathrm{cm}^{3}\right)$.
\end{abstract}

Kata kunci: Gunung Anak Ranakah, metode gravitasi, analisis spektrum, inverse modelling, densitas

\begin{abstract}
Abstrack - Research has been carried out on 3D modeling of the subsurface structure of Mount Anak Ranakah and its surroundings. This study aims to create a map and determine the value of the complete bouguer anomaly, regional anomaly, residual anomaly, subsurface density value and create a $3 D$ model of the subsurface structure. The data used is secondary data, namely satellite gravity anomaly data obtained from the Topex website. Data processing in this study using the gravity method. In this method, gravity correction will be carried out, making a complete bouguer anomaly map, performing spectrum analysis, separating regional and residual anomalies using a butterworth filter and performing inverse modeling using ZondGM3D software to create a 3D model of subsurface structures. The results of the complete Bouguer anomaly map show the anomalous value of the study area between 134.6-209.3 mGal, regional anomaly 147.4-205.9 mGal and residual anomaly between (-12.8)-11.0 mGal. The inverse modeling results show that the subsurface geological structure of Mount Anak Ranakah and its surroundings has a density range between $1.2-3.0 \mathrm{~g} / \mathrm{cm}^{3}$, so that from the range of rock density values it can be estimated that the subsurface geological structure of Anak Ranakah and its surroundings consists of soil rock $\left(1.2-2.3 \mathrm{~g} / \mathrm{cm}^{3}\right)$ andesite $\left.2.40-2.80 \mathrm{~g} / \mathrm{cm}^{3}\right)$ and basalt $\left(2.70-3.0 \mathrm{~g} / \mathrm{cm}^{3}\right)$.
\end{abstract}

Keywords: Mount Anak Ranakah, gravity method, spectrum analysis, inverse modelling, density

\section{Pendahuluan}

Indonesia terletak pada tiga lempeng tektonik besar dunia, yaitu lempeng Indo-Australia, Eurasia dan Pasifik. Hal tersebut menyebabkan Indonesia berada pada daerah rawan gempabumi dan banyak terdapat gunung api. Zona tektonik di Indonesia sangatlah aktif yang diakibatkan oleh pertemuan lempenglempeng dan membentuk jalur-jalur pertemuan yang sangat kompleks. Selain itu, Indonesia adalah negara yang dilintasi oleh dua jalur pegunungan muda, yaitu Sirkum Mediterania dan Sirkum Pasifik yang menyebabkan Indonesia memiliki gunung berapi baik yang masih aktif maupun non aktif yang tersebar di beberapa titik. Indonesia tercatat memiliki sekitar 128 gunung api dengan 90 gunung api di 
antaranya masih aktif dan sering menunjukkan aktivitas vulkanismenya. Dua hal tersebut yang menyebabkan sering terjadi bencana gunung meletus di Indonesia [1].

Gunung Anak Ranakah merupakan gunung api aktif yang terletak di Kabupaten Manggarai, Provinsi Nusa Tenggara Timur dengan letak geografis $120^{\circ} 32^{\prime} 13^{\prime \prime}$ BT dan $8^{\circ} 36^{\prime} 22^{\prime \prime}$ LS. Gunung api ini merupakan gunung dengan tipe strato dengan ketinggian 2.247,5 m diatas permukaan laut. Gunung Anak Ranakah pernah meletus pada 28 Desember 1987 [2].

Metode gravitasi merupakan salah satu metode geofisika yang dapat menggambarkan bentuk struktur bawah permukaan berdasarkan keragaman medan gravitasi bumi yang ditimbulkan karena adanya perbedaan densitas antara batuan [3]. Pada metode gravitasi dimanfaatkan perbedaan nilai percepatan gravitasi pada titik-titik pengukuran di lokasi pengambilan data. Perbedaan percepatan gravitasi mengindikasikan adanya perbedaan densitas batuan yang diakibatkan karena adanya perbedaan jenis batuan di daerah pengambilan data. Sebelum pengambilan data gravitasi dilakukan, biasanya terlebih dahulu dilakukan survei daerah penelitian yaitu menentukan titik-titik pengukuran yang akan dilakukan pengambilan data. Lokasi titik-titik pengukuran harusnya berada di tempat yang mudah diakses, namun medan di lapangan kadang tidak sesuai yang diharapkan dan tidak semua titik pengukuran bisa diakses dengan mudah.

Sekarang ini telah dikembangkan suatu metode baru dalam pengukuran data medan gravitasi yang tidak secara langsung mengambil data insitu. Metode ini dinamakan dengan metode anomali gravitasi citra satelit. Satelit akan memberikan informasi anomali gravitasi dan topografi lengkap dengan data posisi geografis titik ukur di permukaan bumi[4]. Berbagai jenis mineral alam yang terkandung seperti batubara, bauksit, zinc dan beberapa mineral logam lainnya yang sulit dideteksi menggunakan metode geolistrik atau metode geofisika lain yang pengambilan data secara insitu, ternyata dapat dengan mudah dideteksi menggunakan metode gravitasi citra satelit. Data medan gravitasi ini berupa data anomali gravitasi yang sudah dikoreksi hingga koreksi udara bebas yang bisa diakses dari website: http://topex.ucsd.edu/cgi-bin/get data.cgi [5].

Pada penelitian ini dilakukan pemodelan tiga dimensi (3D) untuk mengidentifikasi struktur bawah permukaan Gunung Anak Ranakah berdasarkan nilai densitas batuan daerah setempat menggunakan metode gravitasi. Data yang digunakan merupakan data anomali gravitasi yang diperoleh dari satelit yang telah dikoreksi hingga koreksi udara bebas yang selanjutnya akan dikoreksi bouguer dan koreksi medan untuk mendapatkan nilai anomali bouguer lengkap. Hasil akhir dari penelitian ini diharapkan dapat memberikan informasi mengenai struktur bawah permukaan Gunung Anak Ranakah dan sekitarnya untuk kepentingan studi mitigasi bencana, eksplorasi dan lain-lain.

\section{Dasar Teori}

\subsection{Gaya gravitasi}

Gravitasi berasal dari kata dalam bahasa Inggris yaitu gravity yang artinya gaya berat. Gaya gravitasi dinyatakan oleh Hukum Newton dimana besar gaya gravitasi antara dua partikel dengan massa $m_{1}$ dan $m_{2}$ berbanding lurus dengan hasil kali kedua massanya dan berbanding terbalik dengan kuadrat jarak antara kedua pusat massanya [6]. Berdasarkan hukum tersebut, gaya gravitasi dapat dinyatakan dalam persamaan berikut:

$$
F=G \frac{m_{1} m_{2}}{r^{2}}
$$

Dimana $\mathrm{F}$ adalah gaya gravitasi $(\mathrm{N}), \mathrm{G}$ adalah konstanta gravitasi universal $\left(6,672 \times 10^{-11} \mathrm{Nm}^{2} / \mathrm{kg}^{2}\right)$ $m_{1}$ dan $m_{2}$ adalah massa partikel $(\mathrm{kg})$ dan $r$ adalah jarak antara dua pusat massa $(\mathrm{m})$.

\subsection{Metode gravitasi}

Metode gravitasi merupakan salah satu metode geofisika pasif yaitu metode yang mengukur besar gaya gravitasi yang dipancarkan oleh bumi. Metode gravitasi memanfaatkan medan gravitasi bumi untuk menggambarkan batuan bawah permukaan daerah penelitian berdasarkan keragaman densitasnya. Penelitian menggunakan metode gravitasi pada dasarnya memanfaatkan nilai percepatan gravitasi di area pengambilan data. Perubahan percepatan gravitasi pada satu titik dengan titik lainnya dapat mengindikasikan adanya perbedaan densitas dari bawah permukaan sehingga dapat diartikan terdapat 
perbedaan kandungan pada bawah permukaan bumi [7]. Sekarang ini telah dikembangkan suatu metode pengukuran data medan gravitasi dari satelit lengkap dengan data posisi geografis titik ukur di permukaan bumi. Data anomali gravitasi dan topografi yang diperoleh telah tergrid secara teratur dalam format ASCII_XYZ sesuai batas-batas posisi geografis yang dimasukan serta memiliki akurasi anomali gravitasi sebesar $1 \mathrm{mGal}$. Data ini bisa diakses melalui website Topex [8].

\subsection{Koreksi metode gravitasi}

Pembacaan nilai gravitasi dipengaruhi oleh faktor lingkungan atau kondisi saat melakukan pengambilan data. Alat ukur gravitasi tidak memberikan nilai anomali gravitasi secara langsung karena dipengaruhi oleh beberapa faktor saat melakukan pengukuran gravitasi di suatu titik di permukaan bumi. Hal tersebut berkaitan dengan bumi yang pada kenyataannya tidak bulat, lebih mendekati bentuk spheroid, relief permukaan bumi yang tidak rata, berevolusi dalam sistem matahari, berotasi serta tidak homogen, sehingga percepatan gravitasi di permukaan tidak konstan [9]. Oleh karena itu, untuk mengurangi kesalahan pembacaan nilai gravitasi, maka diperlukan beberapa koreksi yaitu koreksi pasang surut (tidal), koreksi apungan (drift), koreksi udara bebas (free air correction), koreksi bouguer dan koreksi medan. Data anomali gravitasi citra satelit merupakan data yang telah terkoreksi hingga koreksi udara bebas, sehingga langkah selanjutnya yaitu dilakukan koreksi bouguer dan koreksi medan.

\subsection{Estimasi densitas batuan rata-rata}

Densitas batuan merupakan besaran fisis yang sangat penting dalam metode gravitasi. Densitas batuan dipengaruhi beberapa faktor diantaranya adalah densitas butir atau matriks pembentuknya, porositas, dan kandungan fluida yang terdapat dalam pori-porinya. Namun demikian terdapat banyak faktor lain yang ikut mempengaruhi densitas batuan diantaranya proses pembentukan, pemadatan, kedalaman, tekanan, serta derajat pelapukan yang dialami batuan tersebut [10]. Ada beberapa cara yang dapat digunakan untuk menentukan estimasi densitas rata-rata daerah penelitian salah satunya adalah metode Parasnis. Metode Parasnis merupakan metode analitik yang digunakan untuk menentukan estimasi densitas batuan rata-rata dengan mengasumsi topografi daerah penelitian relatif datar [9].

\subsection{Analisis spekstrum}

Analisis spektrum merupakan transformasi Fourier dari suatu lintasan yang telah ditentukan pada peta kontur anomali Bouguer lengkap. Secara umum, suatu transformasi Fourier adalah menyusun kembali suatu gelombang sembarang ke dalam gelombang sinus dengan frekuensi beragam dimana hasil penjumlahan gelombang-gelombang sinus tersebut merupakan bentuk gelombang aslinya. Untuk analisis lebih lanjut, amplitudo gelombang-gelombang sinus tersebut ditampilkan sebagai fungsi dari frekuensinya. Secara matematis hubungan antara gelombang $S_{(t)}$ yang akan diidentifikasi gelombang sinusnya (input) dan $S_{(f)}$ sebagai hasil transformasi Fourier diberikan oleh Persamaan (2) berikut:

$$
S_{(f)}=\int_{-\infty}^{\infty} S_{(t)} e^{-j 2 \pi f t}
$$

dimana $j=\sqrt{i}$.

Pada metode gaya gravitasi, spektrum diturunkan dari potensial gaya gravitasi yang teramati pada suatu bidang horizontal dimana transformasi Fouriernya sebagai berikut [11].

$$
F(U)=\gamma \mu F\left(\frac{1}{r}\right) \quad \text { dan } \quad F\left(\frac{1}{R}\right)=2 \pi\left(\frac{e^{|k|\left(z_{0}-z_{1}\right)}}{|k|}\right)
$$

Dimana $\mathrm{z}_{1}>\mathrm{z}_{0}$ adalah selisih antara ketinggian titik amat dan kedalaman anomali benda, $|k| \neq 0, U$ adalah potensial gravitasi, $\mu$ adalah anomali rapat massa, $\gamma$ adalah konstanta gaya berat dan $r$ adalah jarak. Percepatan gravitasi dihubungkan pada potensial gravitasi oleh persamaan $g=\nabla U$ Gerak vertikal gaya gravitasi yang disebabkan oleh suatu titik massa adalah turunan dari potensial gravitasinya:

$$
F(U)=G m \frac{\partial}{\partial z} \frac{1}{r}
$$




$$
\begin{aligned}
& F\left(g_{z}\right)=G m F\left(\frac{\partial}{\partial z} \frac{1}{r}\right) \\
& F\left(g_{z}\right)=G m \frac{\partial}{\partial z} F\left(\frac{1}{r}\right)
\end{aligned}
$$

Transformasi Fourier pada lintasan yang diinginkan adalah:

$$
F\left(g_{z}\right)=2 \pi G m e^{|k|\left(z_{0}-z_{1}\right)}, z_{1}>z_{0}
$$

Jika distribusi rapat massa bersifat acak dan tidak ada korelasi antara masing-masing nilai anomali gravitasi $(\mathrm{m}=1)$, sehingga hasil transformasi Fourier anomali gravitasi menjadi:

$$
A=C e^{|k|\left(z_{0}-z_{1}\right)}
$$

dimana A adalah amplitudo dan $\mathrm{C}$ adalah konstanta. Untuk memperoleh hubungan antara amplitudo (ln A) dengan bilangan gelombang $(\mathrm{k})$ dan kedalaman $\left(\mathrm{z}_{0}-\mathrm{z}_{1}\right)$ dilakukan dengan logaritma pada Persamaan

(7) dan (8) sehingga bilangan gelombang (k) berbanding lurus dengan spektrum amplitudo.

$$
\begin{aligned}
& \ln A=\ln 2 \pi G m e^{|k|\left(z_{0}-z_{1}\right)} \\
& \ln A=\left(z_{0}-z_{1}\right)|k|+\ln C
\end{aligned}
$$

Persamaan di atas dapat dianalogikan dalam persamaan garis lurus:

$$
y=m x+c
$$

Dimana $\ln A$ sebagai sumbu y dan $|k|$ sebagai sumbu $\mathrm{x}$ dan $\left(\mathrm{z}_{0}-\mathrm{z}_{1}\right)$ sebagai kemiringan garis (gradien).

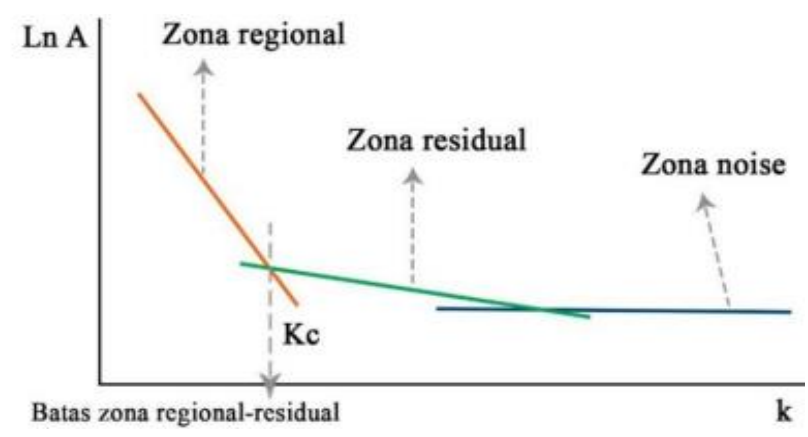

Gambar 1. Kurva $\ln A$ terhadap k [12].

2.6 Pemisahan anomali residual dan regional

Anomali yang terdapat dalam metode gravitasi dikenal dengan anomali bouguer lengkap atau complete bouguer anomaly (CBA). Anomali bouguer lengkap merupakan penjumlahan dari anomali regional dan anomali residual. Kedua anomali tersebut saling berinteraksi sehingga menimbulkan anomali yang tumpang tindih. Oleh sebab itu, kedua anomali tersebut harus saling dipisahkan [3]. Anomali regional merupakan anomali yang bersumber sangat dalam, berukuran besar dan biasanya berkaitan dengan lempeng tektonik sedangkan anomali residual merupakan anomali lokal bersumber dangkal yang ada pada daerah penelitian. Proses pemisahan anomali regional dan residual dalam penelitian ini menggunakan filter Butterworth sedangkan untuk noise sudah tercampur dengan anomali residual karena nilainya yang sangat kecil.

\subsection{Pemodelan gaya gravitasi}

Pemodelan dalam geofisika dapat dilakukan dengan dua metode yaitu forward modelling atau pemodelan ke depan dan inverse modelling (pemodelan inversi). Forward modelling merupakan suatu perhitungan data yang secara teoritis akan teramati di permukaan bumi jika diketahui harga parameter model bawah permukaan tertentu. Dalam pemodelan dicari suatu model yang cocok dengan data lapangan, sehingga model tersebut dianggap menginterpretasikan kondisi bawah permukaan di daerah penelitian [13]. Sedangkan pemodelan inversi (inverse modelling) merupakan kebalikan dari pemodelan ke depan karena dalam pemodelan inversi parameter model diperoleh langsung dari data [14]. 


\section{Metode Penelitian}

Lokasi penelitian ini adalah Gunung Anak Ranakah dan sekitarnya dengan batas geografis antara $120^{\circ} 27^{\prime} 31,01^{\prime \prime}-120^{\circ} 36^{\prime} 8,74^{\prime \prime}$ BT dan $8^{\circ} 35^{\prime} 15,24^{\prime \prime}-8^{\circ} 41^{\prime} 26,08^{\prime \prime}$ LS. Penelitian ini dilakukan bulan JanuariJuli 2021. Data yang digunakan merupakan data anomali gravitasi yang sudah terkoreksi hingga udara bebas yang diperoleh dari website Topex. Data tersebut dilakukan koreksi bouguer dan koreksi medan untuk memperoleh data anomali bouguer lengkap. Data anomali bouguer lengkap tersebut dilakukan griding yang selanjutnya akan dilakukan analisis spektrum untuk mengetahui estimasi kedalaman daerah penelitian menggunakan software Oasis Montaj. Setelah melakukan analisis spektrum selanjutnya akan dilakukan pemisahan anomali regional dan residual menggunakan filter Butterworth di software Oasis Montaj. Selanjutnya dilakukan inverse modelling untuk memperoleh model struktur bawah permukaan. Pada proses pemodelannya dicari parameter model yang memiliki respon yang sesuai, juga mendekati kebenaran berdasarkan data pengamatan. Dalam penelitian ini inverse modelling menggunakan software ZondGM3D untuk memperoleh model 3D struktur bawah permukaan daerah penelitian.

\section{Hasil dan Pembahasan}

Daerah penelitian terletak di Kabupaten Manggarai, Nusa Tenggara Timur yaitu di Gunung Anak Ranakah dan sekitarnya dengan letak batas geografis $120^{\circ} 27^{\prime} 31,01^{\prime \prime}-120^{\circ} 366^{\prime} 8,74^{\prime \prime}$ BT dan $8^{\circ} 35^{\prime} 15,24^{\prime \prime}-$ $8^{\circ} 41^{\prime 26,08 " ~ L S . ~ L u a s ~ l o k a s i ~ p e n e l i t i a n ~ s e k i t a r ~ 11,06 ~ x ~ 16,59 ~ k m ~ d e n g a n ~ j u m l a h ~ t i t i k ~ u k u r ~} 70$ titik.

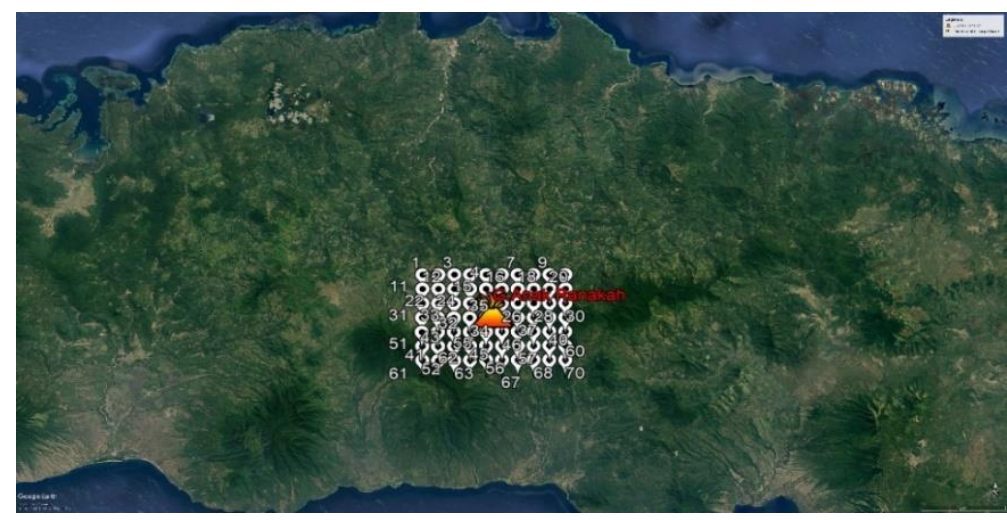

Gambar 2. Lokasi daerah penelitian [15].

Dari peta elevasi (Gambar 3) dapat dilihat bahwa rentang nilai elevasi di Gunung Anak Ranakah dan sekitarnya antara 543,5-1.933,9 $\mathrm{m}$ di atas permukaan laut. Daerah yang memiliki ketinggian tertinggi diwakili oleh warna ungu keputihan dan yang daerah dengan ketinggian terendah diwakili oleh warna biru.

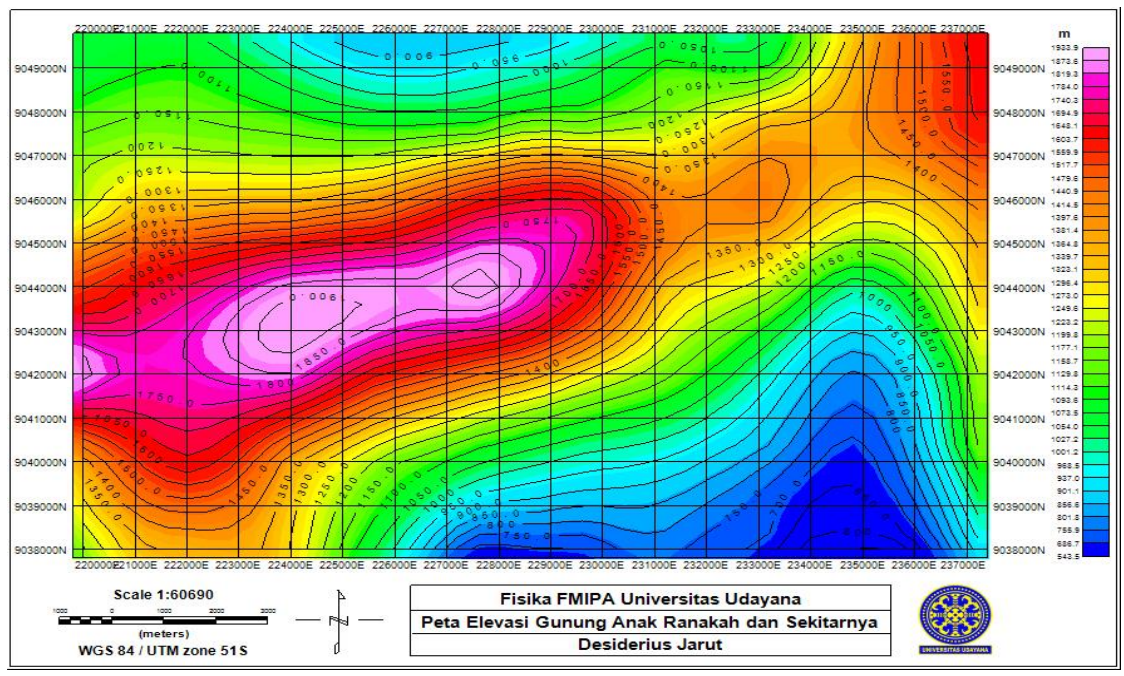

Gambar 3. Peta elevasi Gunung Anak Ranakah dan sekitarnya. 
Sedangkan dari peta complete bouguer anomaly (Gambar 4) diperoleh rentang nilai anomali antara 134,6-209,3 mGal. Anomali tinggi memiliki warna kuning hingga ungu dengan rentang nilai anomali antara 184,5-209,3 mGal dan dapat dilihat bahwa penyebaran nilai anomali tinggi menyebar di barat laut, barat daya dan selatan sedangkan anomali rendah yang memiliki warna biru hingga hijau dengan nilai anomali antara 134,8-183,8 mGal menyebar di bagian tenggara dan timur laut daerah penelitian.

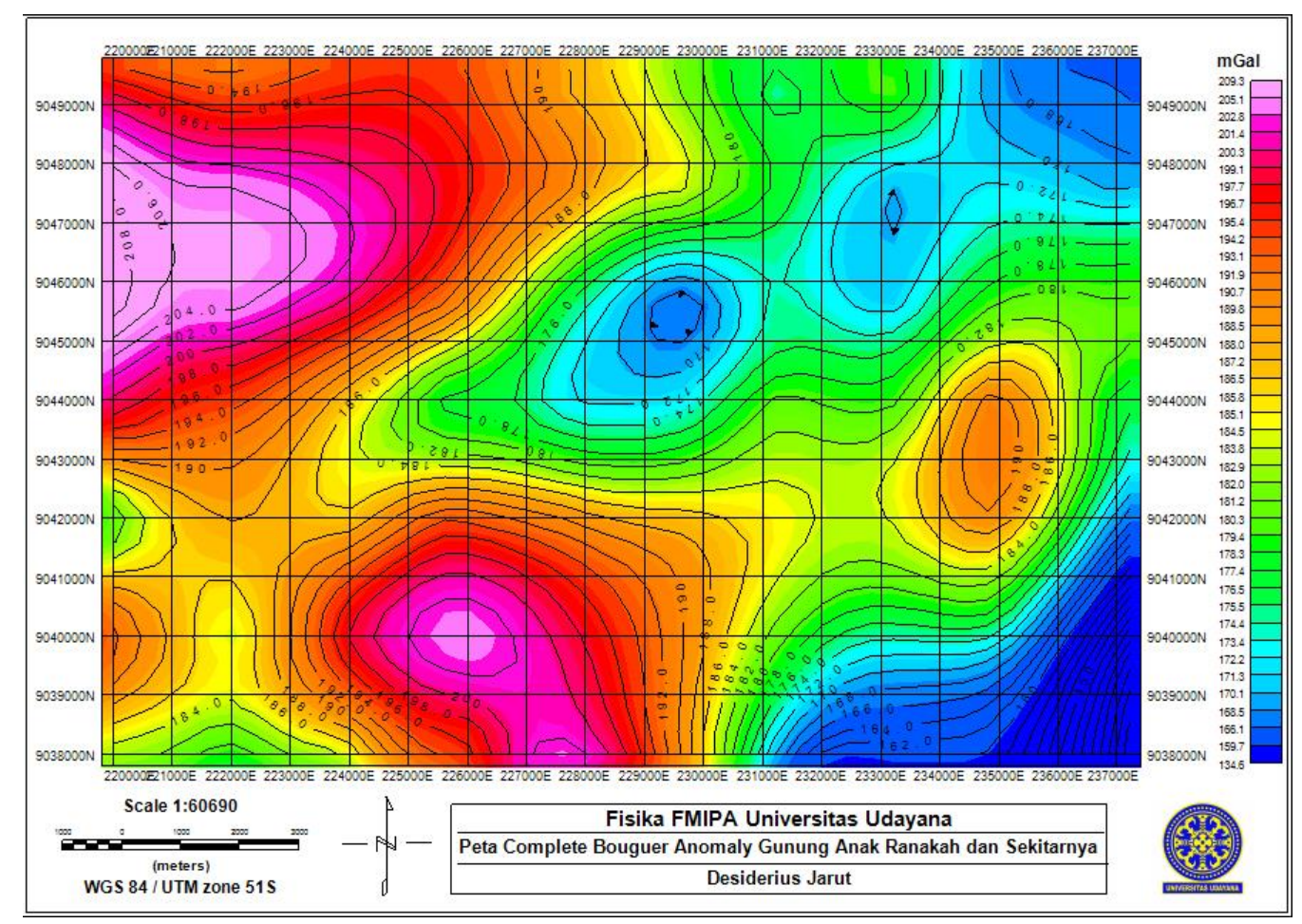

Gambar 4. Peta complete bouguer anomaly Gunung Anak Ranakah dan sekitarnya.

Selanjutnya dari hasil analisis spektrum diperoleh estimasi kedalaman daerah penelitian sekitar 2.100 $\mathrm{m}$ di bawah permukaan (Gambar 5) dengan kedalaman anomali regional sebesar 1.458,65 m dan anomali residual sekitar $693.31 \mathrm{~m}$ yang diperoleh dari gradien persamaan linier amplitudo (ln $A$ ) terhadap bilangan gelombang (k) dibagi dengan $4 \pi$ (Gambar 5).
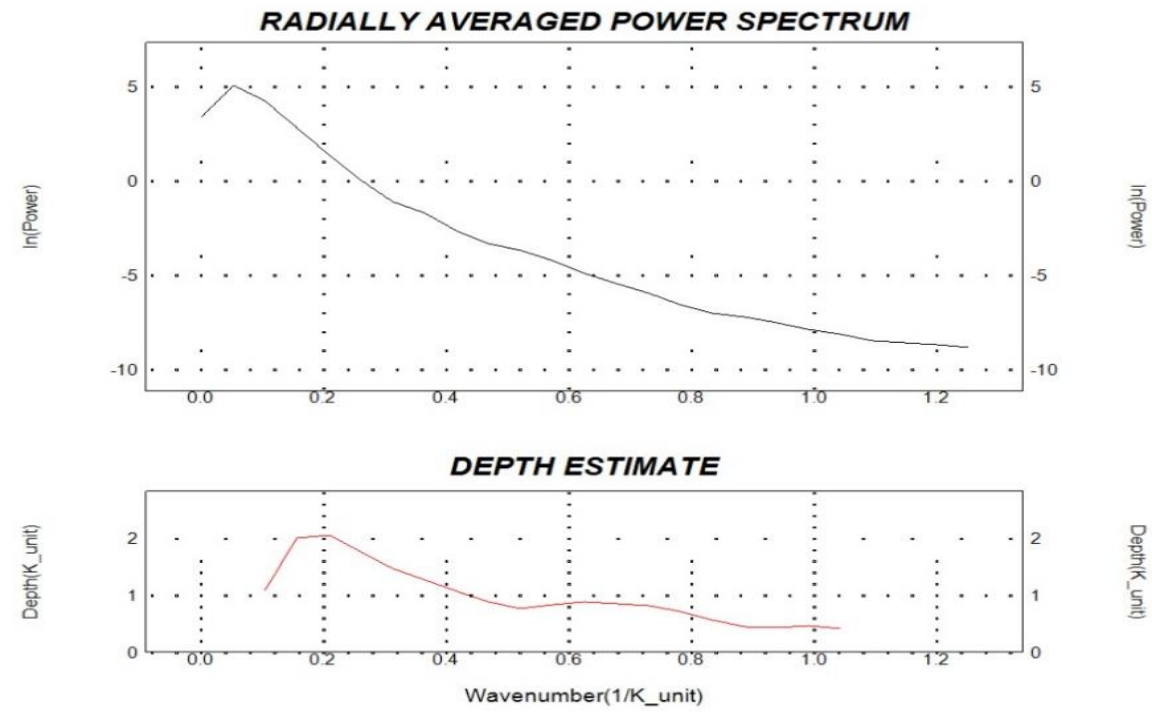

Gambar 5. Hasil analisis spektrum. 


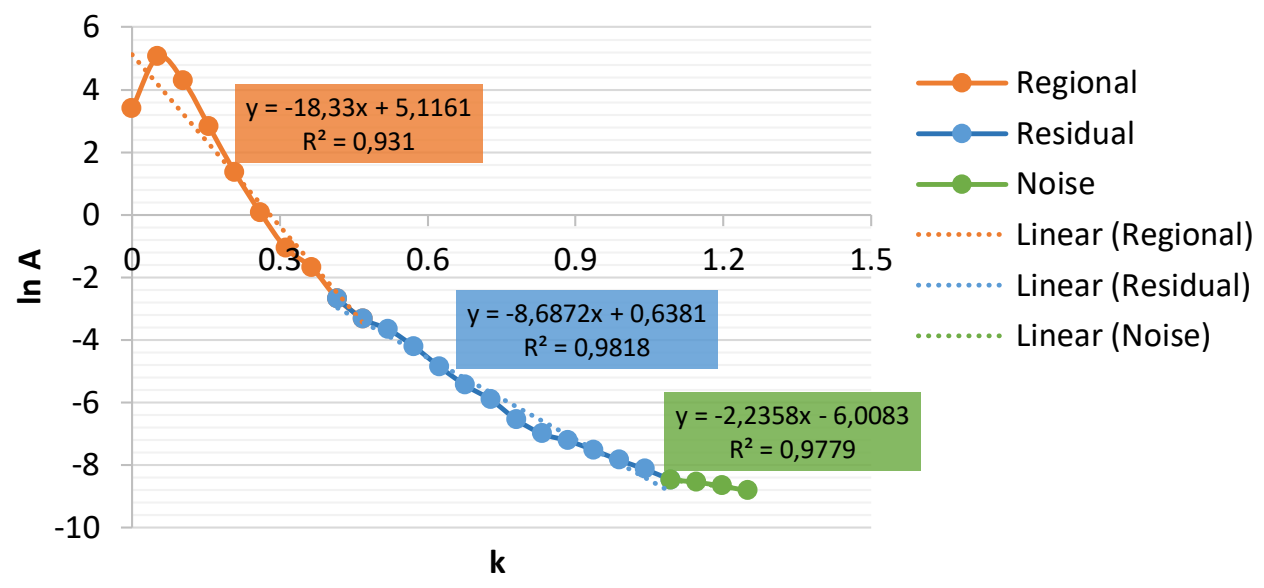

Gambar 6. Grafik ln A vs $k$.

Dari hasil pemisahan anomali menggunakan filter Butterworth diperoleh rentang nilai anomali regional antara 147,4-205,9 $\mathrm{mGal}$ dan anomali residual antara $(-12,8)-11,0 \mathrm{mGal}$. Dari peta anomali regional (Gambar 7) dapat dilihat bahwa nilai anomali tinggi yang memiliki warna kuning hingga ungu dengan nilai anomali antara 183,0-205,9 mGal menyebar di barat laut dan bagian selatan daerah penelitian sedangkan anomali rendah yang memiliki warna biru hingga hijau dengan nilai anomali antara 147,4-182,5 mGal berada menyebar dibagian bagian timur, timur laut dan tenggara.

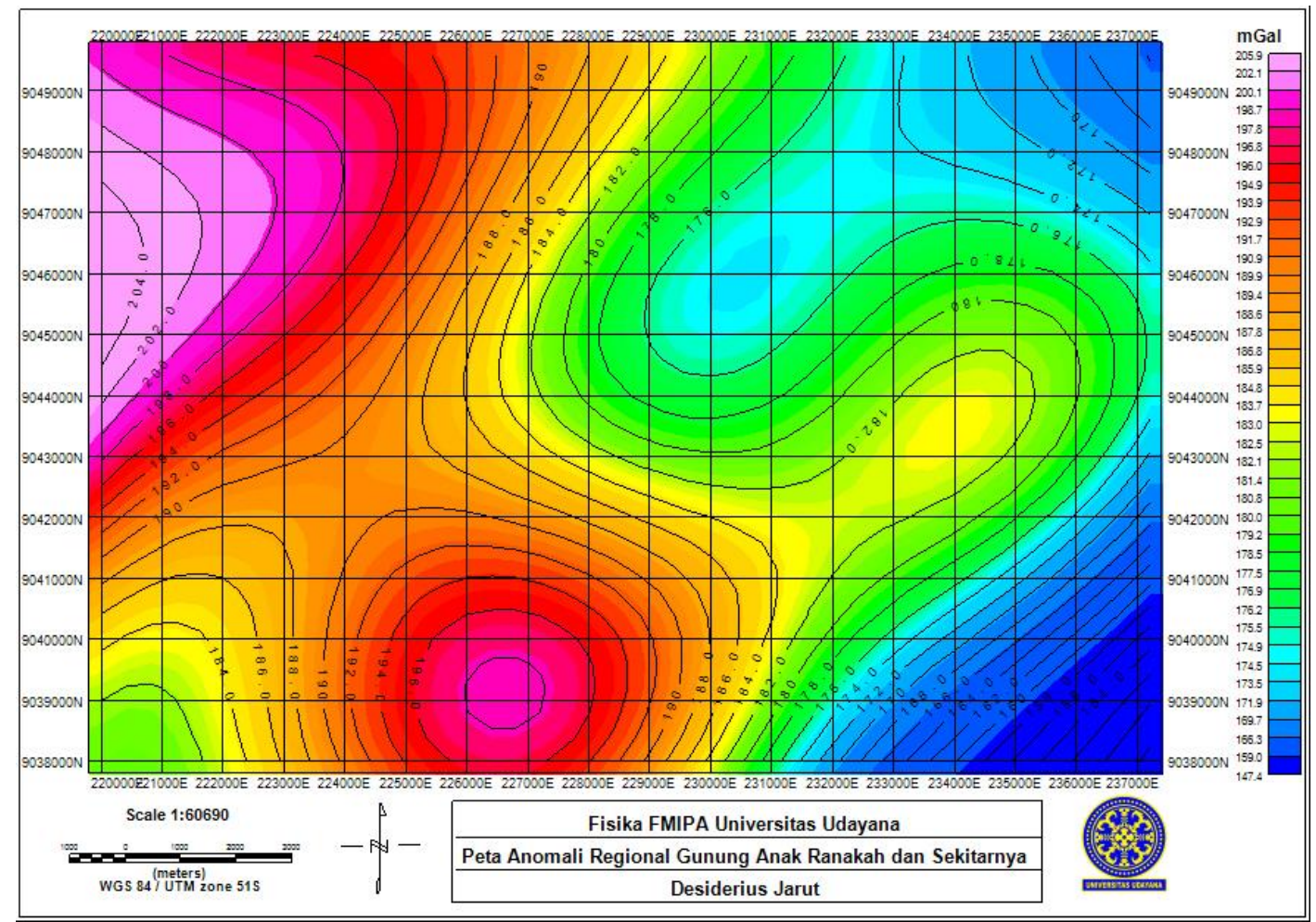

Gambar 7. Peta anomali regional Gunung Anak Ranakah dan sekitarnya.

Sedangkan dari peta anomali residual (Gambar 8) dapat dilihat bahwa nilai anomali tinggi yang memiliki warna kuning hingga ungu dengan nilai anomali $0,6-11,0 \mathrm{mGal}$ menyebar di sekitar Gunung Anak Ranakah dan Gunung Ranakah sedangkan nilai anomali rendah yang memiliki warna biru hingga hijau dengan nilai $(-12,8)-0,4$ mGal sebagian besar menyebar tepat di tubuh Gunung Anak Ranakah, Gunung Ranakah dan Gunung Mandosawu. Anomali rendah pada peta anomali residual menunjukkan adanya batuan dengan rapat massa rendah sedangkan anomali tinggi menunjukkan adanya batuan dengan rapat massa lebih tinggi. 


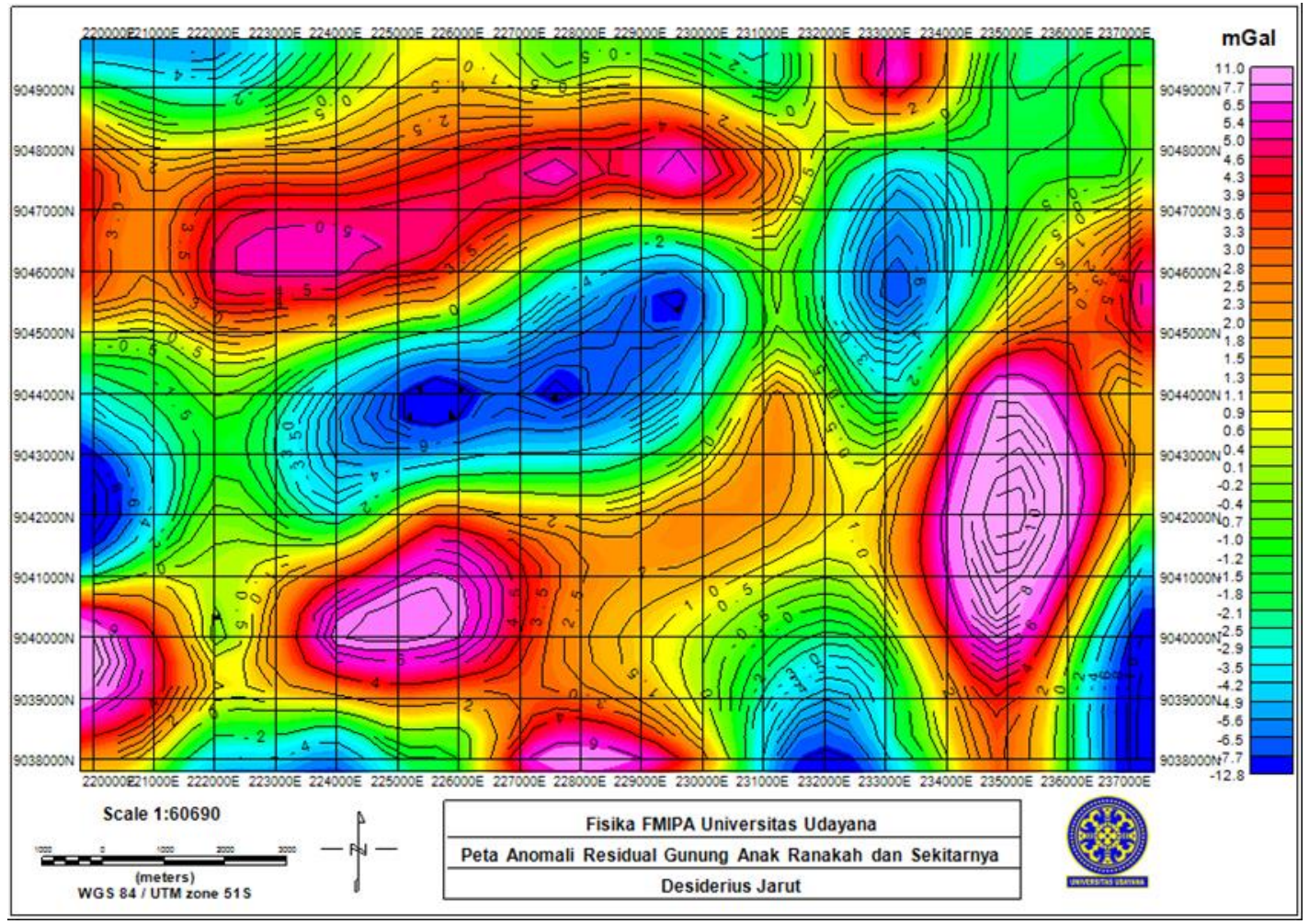

Gambar 8. Peta anomali residual Gunung Anak Ranakah dan sekitarnya.

Setelah dilakukan inverse modelling menggunakan software ZondGM3D diperoleh gambaran 3D struktur bawah permukaan Gunung Anak Ranakah dan sekitarnya seperti pada Gambar 9. Dari gambaran 3D tersebut terlihat bahwa struktur batuan bawah permukaan Gunung Anak Ranakah dan sekitarnya memiliki rentang densitas antara 1,2-3,0 $\mathrm{g} / \mathrm{cm}^{3}$. Dari rentang nilai densitas tersebut dapat diperkirakan jenis batuan bawah permukaan Gunung Anak Ranakah dan sekitarnya dimana setiap densitas diwakili oleh warna tertentu sehingga struktur bawah permukaan Gunung Anak Ranakah dan sekitarnya dapat dibagi menjadi tiga lapisan berdasarkan warna lapisan.

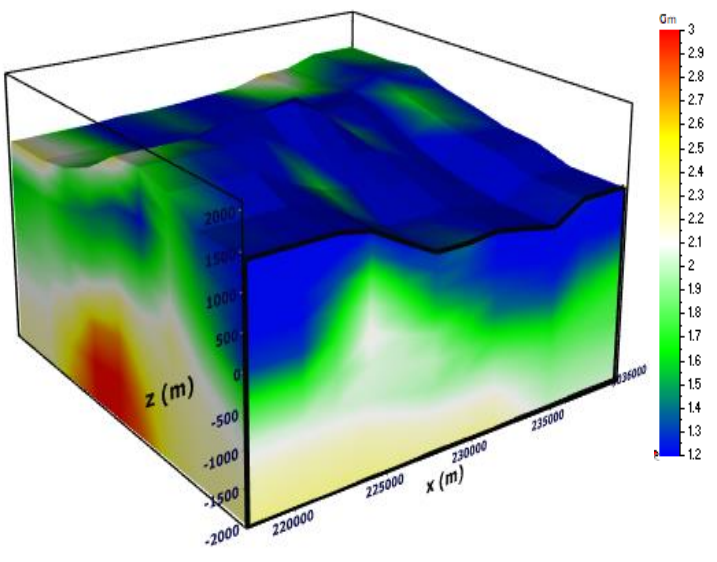

a)

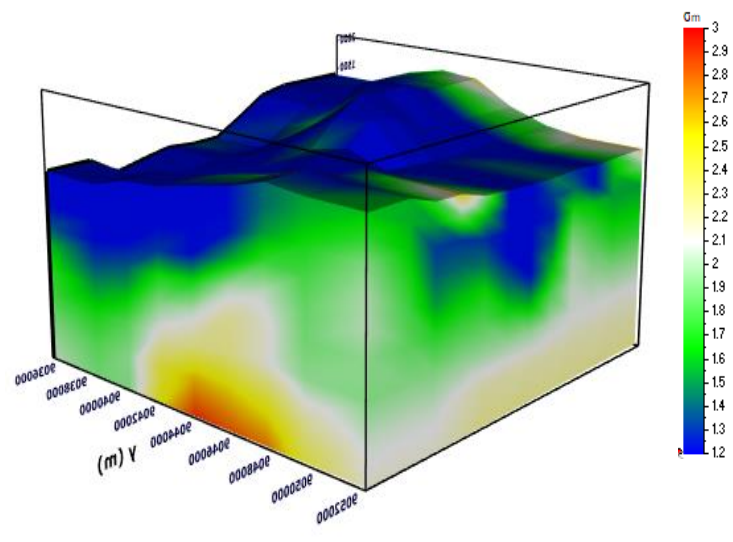

b)

Gambar 9. Model 3D struktur bawah permukaan Gunung Anak Ranakah dan Sekitarnya (a) tampak baratselatan dan (b) tampak timur-utara.

Lapisan pertama memiliki warna biru hingga putih yang memiliki densitas antara $1,2-2,3 \mathrm{~g} / \mathrm{cm}^{3}$. Berdasarkan rentang nilai densitasnya, lapisan tersebut diperkirakan merupakan lapisan sedimen yang mana diduga jenis batuannya merupakan batuan soil. Hal ini sesuai dengan penelitian yang dilakukan oleh Abdurrachman, dkk., (1989), dimana dalam penelitiannya batuan hasil erupsi Poco Ranakah sendiri dari batuan tua ke muda adalah aliran piroklastika Ranakah, lava Ranakah, lava Ranakah-1, lava 
Ranakah-2, lava Ranakah-3, lava Ranakah-4, dan lava Anak Ranakah [16]. Hasil erupsi tersebut kemudian mengalami pengendapan sehingga menjadi batuan sedimen. Lapisan kedua memiliki warna kuning hingga kuning kemerahan yang memiliki densitas $2,40-2,80 \mathrm{~g} / \mathrm{cm}^{3}$, sehingga dapat diperkirakan bahwa lapisan tersebut merupakan jenis batuan andesit. Batuan ini berada pada kedalaman 100-500 m dibawah permukaan Gunung Anak Ranakah dan Gunung Ranakah. Batuan andesit ini diperkirakan terbentuk dari aliran magma yang membeku sebelum mencapai permukaan karena kurangnya tekanan ke atas, sehingga tidak bisa menembus lapisan yang berada diatasnya. Lapisan ketiga memiliki warna kuning kemerahan hingga merah yang memiliki densitas 2,70-3,0 g/ $\mathrm{cm}^{3}$ sehingga dapat diperkirakan bahwa lapisan tersebut tersusun dari batuan basalt yang terdapat di bawah permukaan Gunung Ranakah dan Gunung Anak Ranakah. Batuan ini diperkirakan terbentuk dari dari aliran magma yang membeku sebelum mencapai permukaan karena kurangnya tekanan ke atas sehingga tidak bisa menembus lapisan yang berada diatasnya. Batuan ini berada pada kedalaman 700-2.000 m di bawah permukaan Gunung Ranakah dan Gunung Anak Ranakah. Hal ini sesuai dengan peta geologi daerah setempat dimana struktur geologi di pulau Flores merupakan batuan vulkanik kuarter dimana sebagian besar terdiri dari batuan andesit dan basalt.

\section{Kesimpulan}

Kesimpulan yang didapatkan dari penelitian ini adalah dari peta anomali bouguer lengkap, Gunung Anak Ranakah dan sekitarnya memiliki persebaran nilai anomali gravitasi sebesar 134,6-209,3 mGal, dimana anomali tinggi memiliki rentang nilai anomali antara 184,5-209,3 mGal dan anomali rendah memiliki nilai anomali antara 134,8-183,8 mGal. Sedangkan berdasarkan peta anomali regional, Gunung Anak Ranakah dan sekitarnya memiliki nilai anomali gravitasi antara 147,4-205,9 mGal dan dari peta anomali residual memiliki nilai anomali antara (-12,8)-11,0 mGal. Struktur bawah permukaan Gunung Anak Ranakah dan sekitarnya memiliki tiga lapisan dengan rentang nilai densitas batuan antara $1,2-3,0 \mathrm{~g} / \mathrm{cm}^{3}$ diantaranya batuan soil $\left(1,2-2,3 \mathrm{~g} / \mathrm{cm}^{3}\right)$, andesit $\left(2,40-2,80 \mathrm{~g} / \mathrm{cm}^{3}\right)$ dan basalt $\left(2,70-3,0 \mathrm{~g} / \mathrm{cm}^{3}\right)$.

\section{Ucapan Terima kasih}

Penulis menyampaikan terima kasih kepada Bapak dan Ibu dosen bidang minat Fisika Bumi, Program Studi Fisika, FMIPA UNUD yang telah memberi saran serta masukan terkait penelitian ini. .

\section{Pustaka}

[1] D. Sungkawa, Geografi Regional Indonesia, Jurusan Pendidikan Geografi, Universitas Pendidikan Indonesia, 2008.

[2] G. Tematur, L. J. Tanesib, dan K. R. Pingak, Interpretasi Bawah Permukaan Gunung Anak Ranakah Dengan Pemodelan Dua Dimensi (2D) Berdasarkan Data Anomali Gravitasi Lokal, Jurnal Fisika Sains dan Aplikasinya, vol. 3, no. 1, 2018, pp. 54-58.

[3] J. Purnomo, S. Koesuma, dan M. Yunianto, Pemisahan Anomali Regional Residual pada Metode Gravitasi Menggunakan Metode Moving Average, Polynomial dan Inversion, Indonesian Journal of Applied Physics, vol. 3, no. 1, 2014, pp. 10-20.

[4] O. B. Andersen and P. Kundsen, The Role of Satellite Altimetry in Gravity Field Modeling in Coastal Areas, Phys Chem Earth, vol. 25, no. 1, 2000, pp. 17-24.

[5] F. A. Kurniawan, Pemanfaatan Data Anomali Gravitasi Citra GEOSAT dan ERS-1 Satellite untuk Memodelkan Struktur Geologi Cekungan Bentansari Brebes, Indonesian Journal of Applied Physics, vol. 2, no. 2, 2012, pp 84-95.

[6] R. A. Serway and J. W. Jewett, Physics for scientists dan Engineers, Thomson Brook/Cole, California, 2004.

[7] D. Lestari, Visualisasi Struktur Bawah Permukaan Gunung Merapi Menggunakan Data Anomali Gravitasi Citra Satelit, Skripsi, Jurusan Fisika, Fakultas Matematika dan Ilmu Pengetahuan Alam Universitas Negeri Semarang, 2019.

[8] D. Sandwell, et al., Toward 1-mGal accuracy in global marine gravity from CryoSat-2, Envisat and Jason-1, The Leading Edge, vol. 32, no. 8, 2013, pp. 921-899.

[9] A. A. Martha, Pemodelan 3D Data Gayaberat Lapangan Panas Bumi Ulubelu Tanggamus Lampung, Thesis, Institut Teknologi Bandung, 2011. 
[10] M. Ridha, dan Darminto, Analisis Densitas, Porositas dan Struktur Mikro Batu Apung Lombok dengan Variasi Lokasi dan Kedalaman, Jurnal Fisika dan Aplikasinya, vol. 12, no. 3, 2016, pp. 124-130.

[11] R. J. Blakelly, Potential Theory in Gravity and Magnetic Applications, Cambridge University Press, 1996.

[12] N. Ilmi, Pemodelan 3D Struktur Bawah Permukaan Gunungapi Agung Provinsi Bali Menggunakan Metode Gaya Berat, Skripsi, Jurusan Teknik Geofisika, Fakultas Teknik Universitas Lampung, 2019.

[13] N. Wachidah, Identifikasi Struktur Bawah Permukaan Dareah Potensi Mineral dengan Menggunakan Metode Gravitasi di Lapangan A Pongkor Jawa Barat, Skripsi, Institut Teknologi Sepuluh November, 2017.

[14] F. Wahyuningsih, Pendugaan Struktur Bawah Permukaan dan Reservoar Lapangan Panasbumi Malingping Berdasarkan Analisis Data Gayaberat, Skripsi, Jurusan Teknik Geofisika, Fakultas Teknik Universitas Lampung, 2017.

[15] Google Earth, Gunung Anak Ranakah, 2021, Available from: https://earth.google.com/web/search/Gunung+Anak+Ranakah/, diakses 3 Maret 2021.

[16] E. K. Abdurrachman, et al., Laporan Pemetaan Geologi Kompleks Mandosawu-Ranakah, Kabupaten Manggarai Flores Barat- NTT, Direktorat Vulkanologi, 1989. 